\title{
Domestic Violence Amid Lockdown: A Shadow Pandemic
}

* Abhimanyu Singh

1 Dr. Raj Kumar

\begin{abstract}
The outbreak of global pandemic has not just exposed people to the virus but other factors like domestic violence as well. The aim of this research paper is to highlight the major causes of the increase in the domestic violence during the lockdown. The approach of the research has been both theoretical as well as empirical. Domestic violence has been referred to the abuse by one intimate partner on the other. This domestic abuse can be for various unethical reasons or dissatisfactions pointed out by the abuser and his family. The research has also laid down the key elements of abuse in order to recognize whether the act is abuse or not. Intimidation, humiliating each other, Excessive Control and Physical Injury are the four major key elements. There are various causes for the increase domestic violence however financial instability, unemployment, stress, illiteracy, lack of efficiency of NGOs. It has also explained various effects of the domestic violence on the physical and mental stability of the victim and his family members. The three major laws, Section 498-A of the Indian Penal Code, 1860, the Dowry Protection Act, 1961 and the Protection of Domestic Violence Act, 2005 have been explained along with the relevant case laws. The research has concluded that there is inefficiency in the functioning of the governmental and non-governmental organizations to curb the domestic violence. The research paper has also suggested some of the measures like running campaigns, spreading awareness etc. to curb the domestic violence.
\end{abstract}

Keywords: Domestic violence, Lockdown, Covid-19, Dowry.

\section{Objectives of Research}

1. To study the causes of increase of domestic violence during the Covid-19 pandemic.

2. To co-relate the types of domestic violence with each other.

3. To check the inter-dependency of causes of domestic violence.

4. To understand the key elements of an abuse.

5. To study the effects of the domestic violence on the victim and her family during Covid19 pandemic.

\footnotetext{
* Research Scholar, Faculty of Law, University of Rajasthan. Email:abhimanyurgnul@gmail.com M-+918619603156

1 Associate Professor, Head \& Dean, Faculty of Law, Baba Mast Nath University, Asthal Bohar, Rohtak, Email: austereraj@gmail.com M-+91-9466602200
} 
6. To find what suggestions and measures can be taken to curb the domestic violence.

\section{Introduction}

The act of domestic violence is one of the biggest issues faced especially by the women of every country. While, looking at the statistics of our country, the domestic violence has influenced the life of almost every married woman. Domestic violence is generally known as "Intimate Partner Violence" as this act of violence is performed by one partner on the other. This act of domestic abuse has its effect in both rural as well as urban areas. Though, illiteracy is one of the factors of domestic abuse but with the changing times the greed of establishing one's dominance over the other has been observed prominently.

The law makers of our country have provided several rights to the women who have been subjected to domestic violence against the abuser under various statutes and legislations. Earlier, only married couples were covered in the purview of domestic laws of our country but eventually live-in relationship was given an equal status as to the married couples.

With the outbreak of the virus, the concentration of all the organizations and governments has been diverted towards the spread and measures to control its spread further. This diversion gave the abusers of the domestic violence an opportunity to exercise their dominance upon the victims. It is really important to understand that the victims of domestic violence suffer more as compared to those who are exposed to the virus. This is because they do not even have appropriate resources to reach out for help.

\section{Domestic Violence: Nature \& Meaning}

The term domestic violence refers to any kind of violence faced by anyone in a relationship or family irrespective of their socioeconomic background, colour, sex, caste, race, etc. According to the United States Department of Justice 'Office on Violence against Women' the term domestic violence is defined as a pattern of abusive behavior in any relationship that is used by one 
another intimate partner. ${ }^{2}$ In India, the term domestic violence has been defined under Section $3^{3}$ of the Protection of Women from Domestic Violence Act, 2005. It states that any act, omission or commission or conduct resulting in physical, verbal, emotional, sexual and economic abuse of the victim shall be considered as the domestic violence by the respondent on the victim. This domestic violence takes place between every type of couples may them be heterosexual or homosexual, married or unmarried. As per the United Nation population Fund Report around $2 / 3^{\text {rd }}$ of married Indian women are victims of domestic violence ${ }^{4}$.

The act of domestic violence has been prevalent from time immemorial. In ancient times men were considered superior to women because women were only allowed to do household chores and not earn for their livelihood. The act of domestic violence was considered as a sign of pride for a man in that era. Though women have been provided an equal position as that of a man in the society today but their condition inside the house remains the same. They are still abused, tortured for every minute thing.

There are various forms of domestic violence but physical, mental and sexual violence are the prominent ones. Though both the genders fall prey to the domestic violence but the condition of women is more vulnerable in India and this lockdown has made it worse. The National Commission of Women in its report had stated an increase of $94 \%$ in the cases of domestic violence during the first month of lockdown period. ${ }^{5}$ These statistics gets worse when it comes to the point that not every woman who faces domestic violence reports it. There have been various provisions under various laws, various organizations and associations for the help of the victims but the still the offence of domestic violence is reaching to its heights every succeeding day.

\section{Main Causes of Domestic Violence in Times of Covid-19}

\footnotetext{
${ }^{2}$ U.S. Department of Justice 'Office of Justice Programs', November 2011, https://www.ojp.gov/sites/g/files/xyckuh241/files/archives/factsheets/ojpfs_domesticviolence.html, $25^{\text {th }}$ August, 2020, 5:30 p.m.

${ }^{3}$ Section 3) Definition of domestic violence, the Protection of Women from Domestic Violence Act, 2005, (Act No. 43 of 2005), the Parliament of India.

${ }^{4}$ Youth kiAwaaz "Domestic Violence in India: Causes, Consequences and Remedies" by Ankur Kumar, $7^{\text {th }}$ February, 2010, https://www.youthkiawaaz.com/2010/02/domestic-violence-in-india-causes-consequences-andremedies, $25^{\text {th }}$ August, 2020, 5:35 p.m.

${ }^{5}$ The Economic Times (2020) "India witnessed steep rise in crime against women amidst lockdown, 587 complaints received: NCW", April 17, https://economictimes.indiatimes.com/news/politics-and-nation/india-witnesses-steeprise-in-crime-against-women-amid-lockdown-587-complaints-received-ncw/articleshow/75201412.cms, $\quad 25^{\text {th }}$ August, 2020, 5:47 p.m.
} 
There are various reasons which cause a person to perform the offence of domestic violence. It can be the surroundings of the person that influence him to indulge into such practices or the thing that he himself has witnessed. The outbreak of pandemic has added more reasons to the pre-existing ones and has given an upper hand to the predator to impose his power on the other. Earlier, women used to rush to their parents' house to save them but with the imposition of the lockdown they are trapped inside their own houses. The 68 days lockdown period has shattered all the records of past 10 years of domestic violence. ${ }^{6}$ The following are some of the major reason which has lead drastic increase in the reported cases of domestic violence during the lockdown:

\section{Financial Uncertainty}

The outbreak of the pandemic has cost people not only their lives but their means of livelihood. According to the data released by the Centre for Monitoring Indian Economy, around 1.8 Crore people lost their jobs since April as a result of the outbreak of the virus. $^{7}$ Though unemployment was a pre-existing reason for the domestic violence but the loss of job at such a large scale has made it the biggest reason for increasing domestic violence. The loss of job has not only freezed the current income of the people but has also raised a question on the future job perspectives and opportunities. The stay of man at home has made women more vulnerable to the acts of the domestic violence. As per the National Family Health Survey 2015-16 about 86\% of women who experience violence never sought help. ${ }^{8}$ Now imagine the situation when there are limited means for a woman to reach out to someone for help.

The gender unemployment plays a greater role in the domestic violence. It has been observed that the cases of domestic violence increase with an increase in female employment rate whereas decreases with an increase in the male employment rate. This is because a majority in our country believes "It is the male member of the house who earns and runs the house." This fact creates a psychological impact on a man that he is unable

\footnotetext{
6 The Hindu "Domestic Violence complaints at a 10-year high during Covid-19 lockdown", 22 nd June, 2020, https://www.thehindu.com/data/data-domestic-violence-complaints-at-a-10-year-high-during-covid-19lockdown/article31885001.ece\#: :text=During\%20the\%20first \%20four\%20phases,not\%20seek\%20help\%20in\%20I ndia, $26^{\text {th }}$ August, 2020, 10:08 a.m.

7 DNA India "COVID-19 pandemic impact: 50 Lakh salaried jobs lost in July, 1.8 Crore since April, says CMIE", $19^{\text {th }}$ August, 2020,https://www.dnaindia.com/business/report-covid-19-pandemic-impact-50-lakh-salaried-jobs-lostin-july-18-crore-since-april-says-cmie-2838404, 26 ${ }^{\text {th }}$ August, 2020, 10:15 a.m.

${ }^{8}$ Ibid 5.
} 
to earn and feed his family. Therefore, it brings a wave of anger out of him in the form of violence.

2. Stress

This factor is interdependent with the factor of unemployment and has played a major role in increasing the cases of domestic violence amid lockdown. The outbreak of virus, earthquakes, hurricanes and much more has created a huge impact on the lives of people both physically and mentally. The future instability of their lives and career has created a huge impact on the psyche of a person. When this mental pressure or stress increases it takes the form of violence. There are researches that have proved that intimate partner violence (domestic violence) is associated with psychological stress of a person. ${ }^{9}$ The Indian Psychiatric Society had reported $20 \%$ increase in the mental health concerns ${ }^{10}$ during the lockdown period. In some cases, low self-esteem in men gives birth to stress and results in the action of domestic violence against the women.

\section{Illiteracy}

Illiteracy has been playing a prominent role in the increase of the domestic violence especially in India. A research has revealed that in most of the cases of domestic violence, the victims and abusers both belong to the age group of 35-45, scheduled caste, uneducated, couple with more than 2 children, labourers and much more. ${ }^{11}$ The education of a person helps to a great extent in avoiding the crimes. In a community where violence against women is understood as a matter of pride, the low rate of literacy affects their thinking capability. ${ }^{12}$ Such people take violence as a means to communicate instead of words. Therefore, education plays an imminent role in reducing the rate of domestic violence especially in rural areas.

\footnotetext{
9 Science Direct "The psychobiology of stress and intimate partner violence", July 2019, https://www.sciencedirect.com/science/article/abs/pii/S0306453018305821, 26 $6^{\text {th }}$ August, 2020, 10:25 a.m.

${ }^{10}$ Financial Express, "Lockdown has affected mental health of many - what needs to be done to avoid panic", $23^{\text {rd }}$ May, 2020, https://www.financialexpress.com/opinion/lockdown-has-affected-mental-health-of-many-what-needsto-be-done-to-avoid-panic/1968040/, $26^{\text {th }}$ August, 2020, 10:32 a.m.

${ }^{11}$ The Internet Journal of Health "Epidemiological correlates of domestic violence in married women in urban area of Ludhiana, Punjab, India" by Chaudhary, A., Girdhar, S. and Soni, R.K. (2009), Vol. 9 (1), $26^{\text {th }}$ August, 2020, 7:00 p.m.

12"Violence against women in relation to literacy and area of residence in Ethiopia" by Negussie Deyessa, Yemane Berhane, Mary Ellsberg, Maria Emmelin, Gunnar Kullgren, and Ulf Högberg, $\quad 25^{\text {th }}$ February, 2010, https://www.ncbi.nlm.nih.gov/pmc/articles/PMC2830802/, 27 ${ }^{\text {th }}$ August, 2020, 9:38 a.m.
} 
Illiteracy is such a cause due to which a woman is totally helpless and falls prey to the domestic violence every second day. Even in Urban areas the rate of illiteracy of women is comparatively higher as compared to that of women. According to a research, the illiteracy rate of women has been found higher in the urban areas of 8 States and 2 Union Territories and the in rural areas of 13 States and 1 Union Territory as compared to those of men. ${ }^{13}$ The suppressed voices of such illiterate women are almost lost in the silence of this lockdown.

\section{Addiction}

It has been proven that the act of domestic violence is the result of addiction of alcohol and drugs in most of the cases. The addiction sometimes reaches to such a level that people even rape or kill their partners either in the want of such substances or when intoxicated. A man under the influence of such substances is also more likely to abuse a woman physically as well as sexually. The drinking patterns of men are associated with the marital violence across all the social and ethnic groups of classes. ${ }^{14}$

At the initial stage of the lockdown, the liquor shops were shut down. The move of the government to open the liquor shops at a later stage had two fold impacts on most of the households. First, they did not have any means to earn money for their livelihood which lead to a chaos amongst the family for the requirement of money for the alcohol. Secondly, this demand of money and consumption of alcohol has been proved to be a helping hand in the increase of domestic violence cases.

A study by the "Aids and Behaviour Journal" has found that violence against married women in India has been increasing by the consumption of alcohol by their intimate partners. ${ }^{15}$ Alcohol consumption has always been a reason for the increase in domestic violence in India. The relaxation on sale and purchase of alcohol has made it worse.

\footnotetext{
13“"Gender equality in India hit by illiteracy, child marriages and violence: a hurdle for sustainable development" by Kishor Parashramji Brahmapurkar, Department of Community Medicine, Government Medical College, Jagdalpur, Bastar, 494001 Chhattisgarh, India, $26^{\text {th }}$ October, 2017, https://www.ncbi.nlm.nih.gov/pmc/articles/PMC5847257/ $27^{\text {th }}$ August, 2020, 1:25 p.m.

${ }^{14}$ The National Academies Press "Understanding Violence Against Women" by Nancy A. Crowell and Ann W. Burgess, Pg 55, https://www.nap.edu/read/5127/chapter/5, $27^{\text {th }}$ August, 2020, 7:39 p.m.

${ }^{15}$ The CoronaVirus Pandemic "India's resumption of alcohol sales during lockdown is fuelling a rise in domestic violence" by RomitaSaluja, 20 $0^{\text {th }}$ May, 2020, https://www.scmp.com/week-asia/healthenvironment/article/3085319/indias-resumption-alcohol-sales-during-lockdown, $28^{\text {th }}$ August, 2020, 5:00 p.m.
} 
Several women gathered in front of the liquor shops amid lockdown to protest to relaxation on liquor in order to control domestic abuse against them. ${ }^{16}$

\section{Lack of Efficiency of $N G O s$}

The sudden announcement of lockdown has led thousands of people and organizations without any proper planning and resources. The situation had become worse for those women who were facing domestic abuse in their own houses. Although, some NGO's are extending their help through telephonic and web counseling but still are unable to help each and every women due to their own challenges. There have been worldwide rise in the cases but most of the cases are left unreported as the victims and abusers are living together $24 * 7$.

Some of the NGO workers have also stated that in case of emergency, the police officials are contacted for the rescue. ${ }^{17}$ But in this situation of the global pandemic, even the police officials are unable to give other cases a priority. Earlier, the members from such NGOs used to visit to such women who are vulnerable to the domestic violence and offer them help. But with the imposition of the lockdown, it has become a challenge for the NGOs because of two major reasons: i) Restricted movement of citizens due to outbreak of virus ii) The abuser and victim reside together throughout the day and night. These challenges have acted as a factor in increasing the violence against the women.

\begin{tabular}{|l|l|l|l|}
\hline $\begin{array}{l}\text { Women afraid } \\
\text { of the husband }\end{array}$ & $\begin{array}{l}\text { Physical } \\
\text { violence (in \%) }\end{array}$ & $\begin{array}{l}\text { Emotional } \\
\text { violence (in \%) }\end{array}$ & $\begin{array}{l}\text { Sexual violence } \\
\text { (in \%) }\end{array}$ \\
\hline Most of the times & 53.9 & 31.1 & 17.3 \\
\hline
\end{tabular}

${ }^{16}$ Ibid.

${ }^{17}$ The Carvan "Lockdown and domestic violence: As NGOs struggle to support women at risk, government plays catch up" by AathiraKonikkara, 15 ${ }^{\text {th }}$ April, 2020, https://caravanmagazine.in/gender/lockdown-domestic-violencengo-struggle-government-catch-up, $28^{\text {th }}$ August, 2020, 5:15 p.m. 


\begin{tabular}{|l|l|l|l|}
\hline Sometimes & 28.6 & 12.1 & 5.4 \\
\hline Never & 16.4 & 7.1 & 3.0 \\
\hline Total & 29.8 & 13.8 & 6.6 \\
\hline
\end{tabular}

'Percentage of ever-married women age 15-49 who have ever experienced emotional, physical or sexual violence by their husband, India 2015-16'.

Source: National Family Health Survey 2015-16 ${ }^{18}$

\section{Key Elements of Abuse in Times of Covid-19}

\section{Intimidation:}

The primary and essential element of the abuse is "Intimidation". When a person tries to threaten his intimate partner or induce fear in him, such an action amounts to intimidation. Generally, such acts are performed by a partner over the other to establish his dominion status. The abusers took advantage of the worldwide lockdown. They knew that even if they abuse the victim, the victim shall not be in a position to reach out to her parents or someone else for help.

This mindset of the abuser gave him strength to intimidate his partner and abuse her mentally, physically and sexually.

\section{Humiliating each other:}

The second essential element of abuse is "Humiliation". The actions of humiliating someone in order to abuse them mentally are one of the forms of domestic violence. These actions are generally performed by the male partner and his family when the women is unable to bear child/male child, unable to bring enough money after marriage or unable to manage the household chores according to them. The abuser performs such actions of humiliation to fulfill his unethical demands from the female and her parents. The situation becomes more heart breaking when such scenarios occur in families who are highly educated.

\footnotetext{
18“National Family Health Survey (NFHS-4), 2015-16, India” Table 16.12, Pg 590, December, 2017 http://rchiips.org/nfhs/NFHS-4Reports/India.pdf, $28^{\text {th }}$ August, 2020, 11:20 p.m.
} 


\section{Excessive Control:}

The third element which is required to construe as an abuse is "Excessive Control" by the intimate partner. This excessive control can be in financial form where one partner does not allow the other partner to spend money for their essentials. This control can also be in the form of social control where one partner controls the social life of the other by restricting them or controlling them. The pandemic has burdened people with stress and financial constrains and brought violence along with it. These financial constrains were an opportunity for the abusers to abuse the victims and harass them mentally, financially and emotionally.

\section{Physical injury:}

The most important and common element of the abuse is the "Physical Abuse". When the abuser uses various means to physically hurt the victim deliberately then such type of violence is considered as physical violence. These types of actions are generally performed by the abuser either during an argument or in the influence of alcohol or drugs. Several women who were usual victims of domestic violence testified that there was a reduction in the violence when there were restrictions on the sale and purchase of liquor. After the relaxation of the sale of the liquor, they stated that their partners resumed physical violence as soon as they started consuming the liquor.

\section{EFFECTS OF DOMESTIC VIOLENCE IN TIMES OF COVID-19}

The effects of the domestic violence can be severe and immeasurable. The consequences of the domestic violence are not just dealt by the victim but her children as well as her parents. A study has revealed that $50 \%$ of the rapes of the women above the age of 30 are committed by their own partners. ${ }^{19}$ It has been noted that a woman gets more injured when she has been hurt by her own intimate partner physically or sexually. ${ }^{20}$ The effect of domestic violence fades away from the body but leaves a dark impression on the minds of the victims and witnesses. Sometimes the mental trauma increases to such an extent that such women end their own lives.

This effect first leads the victim to isolate themselves from everyone gradually. The physical violence leaves marks on their bodies which lead them to embarrassment. The children who

\footnotetext{
19 The National Academies Press "Understanding Violence Against Women” by Nancy A. Crowell and Ann W. Burgess, Pg 77-78, https://www.nap.edu/read/5127/chapter/5, 28 ${ }^{\text {th }}$ August, 2020, 11:36 p.m.

${ }^{20}$ Ibid.
} 
witness domestic violence between their parents are more likely to get prone to the psychological problems, fears, stress, sleep disorders and much more.

Different studies show that the witnesses of domestic violence have different impact on both the genders. The boys may be more likely to adopt the traits of their fathers and think that this may be the probable solution to the situation whereas the girls who witness maternal abuse may adopt her actions.

Some women show up all the courage to fight up against the violence and leave their partners' house to become independent. After this step, she is subjected to various conditions in the society which may either 'make her' or 'break her'.

\section{LAWS RELATED TO DOMESTIC VIOLENCE IN INDIA}

There are three major laws in India that deals with the domestic violence and provides protection to the women suffering from it. These are as follows:

\section{- Section 498-A of the Indian Penal Code, $1860^{21}$}

The provision of this section provides a married woman protection against the cruelty or violence of her husband and his relatives. The provisions of this section provides the woman protection against her husband and his relatives only if they tried to cause the woman to commit suicide or cause her any injury or harass her to bring any valuable property or meet any unlawful demand. The court has also explained the meaning of cruelty in the case of Inder Raj Malik v. Sunita Malik. ${ }^{22}$

If the guilt of the accused is proved in the court of law then they shall be punished with an imprisonment that may extend up to three years and shall be liable for fine. It has also been held by the court that it is not necessary for the women to prove the physical violence, even denial of conjugal rights would fall under the provisions of section 498-A of cruelty. ${ }^{23}$

\section{- The Dowry Prohibition Act, $1961^{24}$}

\footnotetext{
${ }^{21}$ Section 498-A) Husband or relative of husband of a woman subjecting her to cruelty, the Indian Penal Code, 1860 (Act No. 45 of 1860), the Parliament of India.

${ }^{22}$ Inder Raj Malik v. Sunita Malik, 1986 (92) CRLJ 1510.

${ }^{23}$ Ramesh DalajiGodad v. State of Gujarat II (2004) DMC 124.

${ }^{24}$ The Dowry Prohibition Act, 1961 (Act No. 28 of 1961), the Parliament of India.
} 
The provisions of the Dowry Prohibition Act, 1961 deals with the issues and offences related to dowry. The term dowry means "a specific amount of money that the parents of the bride give away to the family of groom during the ceremonies of marriage in the form of money, property, jewelries etc." The Court has made it clear that the term has been only defined under section 2 of the Dowry Prohibition Act, 1961. ${ }^{25}$ Earlier, dowry system was a considered as a ceremony that was performed by the parents of the bride but later on it was abolished as many women were subjected to violence or cruelty in the name of dowry. One of the important conditions in order to be convicted for the offence of dowry is that such demand of dowry should be made by the accused in nexus with the marriage only. ${ }^{26}$

The act deals with different types of offences related to dowry and the rules \& regulations in regards to the acceptance and giving of dowry. The provisions under this act, acts in consonance with the provisions of the Indian Penal Code, 1860.

\section{- The Protection of Women from Domestic Violence Act, 2005 27}

The Protection of Women from domestic violence Act was the first act that was specifically formulated to deal with the issues related to domestic violence against women in India. This act was enacted a year later of its formulation. This was the major step towards the safety and security of women in India. This act provides with a specific definition of domestic violence under Section $3^{28}$ of the Act. The rights of a married woman are explicitly recognized by different provisions of the Act. The act also levies several punishments for the offenders of the provisions of this Act.

The provisions of this act are also applicable to those couples who are living in live-in relationship. ${ }^{29}$ However, the Court has laid down certain exceptions for the entitlement of live-in relationship couples. The Court has held that only following live-in relationship couples are entitled to the benefits of the act $^{30}$ :

i) There must be a cohabitation similar to married couple;

\footnotetext{
${ }^{25}$ Shanti v. State of Haryana (1991) 1 SCC 371.

${ }^{26}$ Raminder Singh $v$. State of Punjab, (2014) 12 SCC 582.

${ }^{27}$ The Protection of Women from Domestic Violence Act, 2005 (Act No. 45 of 2005), the Parliament of India.

${ }^{28}$ Section 3) Domestic Violence, the Protection of Women from Domestic Violence Act, 2005 (Act No. 45 of 2005 ), the Parliament of India.

${ }^{29}$ D. Veluswamy v. D. Patchaiammal (2010) 10 SCC 469.

${ }^{30}$ Ibid.
} 
ii) The couple must have a legal age to marry;

iii) They should be competent to marry;

iv) They must be living voluntarily with each other;

v) They must live together in a shared household.

The Court has also held that the Act shall have a retrospective effect. The Act shall be applicable to the cause of action even if it took place before the Act came into the force. ${ }^{31}$

\section{CONCLUSION}

The aim of the research paper has been achieved to an extent. The research paper has successfully examined the causes of the increase of domestic violence in the times of Covid-19 through theoretical as well as empirical research. The abovementioned key elements have also made the fact very clear that there are several elements constitute the act of domestic violence whether together or separately.

There are different causes for the performance of the act of domestic violence by the abusers. But in the times of Covid-19, the factors of lack of resources, mental stress and financial instability have been proved as the biggest evil for the women staying at home. This time of isolation has forced them to stay with their abusers as this is the only resort available to them. It has been found out that the causes of the domestic violence are inter-dependent to each other.

It has also been analyzed that the domestic abuse has its affect on the physical state, mental condition and the social life of a victim. The mindset of the witnesses of the domestic violence is also affected to a great extent. However, both the effect of witnessing the abuse may also depend upon how the witness observes the act. They may either learn a lesson to not to repeat the same act in future or may also take abuse as the only solution to tackle the situation.

This is a well known fact that there are limited statutes regarding the protection of women from the act of domestic violence. Though the Penal Laws and other acts also contain various other provisions in regards to the act of domestic violence but are not efficient enough in its implementations. The country is in dire need for various measures and their implementation to curb the domestic abuse as the number of decrease or increase in the figures of domestic violence cannot defy the ground reality.

\footnotetext{
${ }^{31}$ Krishna Bhatacharjee v. SarathiChoudhury (2016) 2 SCC 705.
} 


\section{WAY FORWARD}

The present situation of the cases of domestic violence in our country has clearly proved that our country requires proper implementation of the existing legislations. The government should take an initiative to spread awareness through radio, television programs, advertisements, caller tunes etc. so that victims may try to reach out for help. The government should also highlight the modes through which complaint can be made. The government should also direct the health care providers and the police authorities to ensure that every complaint of the domestic violence shall be given same preference as that of Covid-19 patients. Mental health shall also be given a priority along with the physical health of every person.

The government should give a free hand to the NGOs and other mental health organizations to carry out their campaigns for the protection of victims of domestic violence. The Central Government should direct State Governments to ensure the smooth functioning of the helplines

for the domestic violence. People should also be persuaded to intervene if they suspect any such violence. Also, people should be made aware of different campaigns like "Bell Bajao" against the domestic violence. 